Research article

\title{
Land use and forest cover on private parcels in the Upper Midwest USA, 1970 to 1990
}

\author{
Daniel G. Brown \\ University of Michigan, School of Natural Recources and Environment, Ann Arbor, Michigan MI 48109-1115, \\ USA; (e-mail: danbrown@umich.edu)
}

Received 1 October 2002; accepted in revised form 6 May 2003

Key words: Agricultural abandonment, Forest regrowth, Land use, Recreational development, Remote sensing

\begin{abstract}
This paper analyzes the interactions between land use and forest cover in the Upper Midwest, USA from 1970 to 1990. New data are presented and interpreted to evaluate the effects of land-use changes, especially abandonment of agriculture and dispersed development, on forest cover throughout the region. Forest-cover data were collected from Landsat satellite imagery and land use was interpreted from aerial photographs for land parcels, based on archival maps of land ownership. In general, forest cover increased throughout the region and throughout the period. Simultaneously, the area used for agriculture declined, much of it being converted to natural uses, and the area of land in low density residential development increased. Forest cover increased most rapidly on low density residential lands and in counties in which a large percentage of homes were for seasonal use (i.e., vacation homes). The data suggest that the transformation of the region from an extractive (i.e., forestry and agriculture) to a recreation-based service economy has played a significant role in the increasing forest cover observed throughout the region.
\end{abstract}

\section{Introduction}

Understanding changes in landscape pattern requires understanding of both biophysical and socioeconomic patterns and processes. Biophysical explanations of landscape change include climate, soils, and terrain as the abiotic template on which resources become available to vegetation communities and within which landscapes evolve (Swanson et al. 1988; Bailey 1996). Processes of interspecific competition, dispersal, herbivory, and disturbance all contribute to the formation of landscape patterns through independent effects and interactions with vegetation and the abiotic template (Levin and Paine 1974; Okubo 1975; White and Pickett 1985; Pastor et al. 1993). Human use and management of land, i.e., how people relate to a landscape as a source of livelihood, shelter, recreation, and/or industry, are powerful forces shaping patterns and dynamics in human-occupied landscapes
(Turner et al. 1995). Understanding and managing landscape change, therefore, requires understanding the socioeconomic processes that contribute to those patterns (Burgess and Sharpe 1981; Delcourt 1987; Foster 1992; Medley et al. 1995; Jenerette and Wu 2001; Nagashima et al. 2002).

Many human land-use activities, especially those related to agriculture and natural resources extraction, are dependent on existing biotic and abiotic patterns and processes and result in patterns that are determined to some extent by the natural environment (Huston 1993; Meyer 1995). However, human activity, especially in the developed world, is increasingly characterized by industrial and service activities and by trade, communication, and interaction among landscapes and regions, such that human contributions to landscape dynamics are decreasingly dependent on in situ resources and increasingly independent forces for landscape change (Grübler 1994). 
Land-use changes in rural North America during the past several decades have been affected by changes in the national-level agricultural markets and policies (Lant et al. 2001), increasing international trade, fluctuating rural demographics (Johnson and Beale 1998), and substantial increases in wealthdriven recreational development (Stynes 1997). Abandonment of farms can result in increased tree cover, biomass, and carbon storage if lands are left to undergo secondary succession or are planted with trees (Pickett 1982). Land development may reduce or slow the gains in tree cover due to agricultural abandonment. However, land development, if driven by demands for recreation and aesthetic amenities, may result in preservation or restoration of forest cover. What remains unclear is the nature of this tradeoff and the degree to which different kinds of land-use change have actually affected changes in forest cover.

An important distinction in this work is that between land use and land cover. I define land use as human activity on the land (in sensu Turner et al. 1995). Land-use is influenced by economic, cultural, political, historical, and land-tenure factors at multiple scales. Land cover, on the other hand, is one of the many biophysical attributes of the land that affect how ecosystems function (in sensu Turner et al. 1995). Forest cover is the only land-cover variable I use here.

Many landscape ecological processes, including land-use change, are nested within a hierarchy of spatial scales that describes multiple levels of cause and effect related to these processes. At the finest scales, land use varies among individual ownership parcels, which are owned and managed by households or corporations that make the decisions that affect land cover. These decisions and activities are nested within regional, national, and global contexts that impose economic, cultural, social, and political limitations on these decisions and the resultant outcomes. This multi-scale framework, then, implies a need to consider hierarchy theory (Allen and Starr 1982), which suggests that a study of forest-cover change at the landscape scale consider both the dynamics at a finer scale and the constraints on the landscape at coarser scales.

Forests covered most of Eastern North America during European settlement, but most of the forests had been harvested by the early- $20^{\text {th }}$ century (Williams 1989). Subsequently, forests have regrown on vast areas of marginally productive lands that were taken out of agricultural land use. The dynamics of forest regrowth have implications for both availability of habitat for forest wildlife and for the amount of terrestrial carbon storage. Fan et al. (1998) estimated that the temperate forests of North America are likely candidates as important sinks of atmospheric carbon. An analysis of forest inventories showed that the overwhelming majority of measured biomass increase in the Eastern Deciduous forests of North America can be explained by such land-use changes, with very little contribution from enhanced growth rates due to warming and atmospheric deposition (Caspersen et al. 2000). Though there is evidence that the trend of forest regrowth has slowed in New England (Foster 1992), the same trend continues in the Upper Midwest. The link between land-use and forest-cover change is, therefore, important for explaining past and future carbon sequestration rates. However, because there has been relatively little research on the influence of human land-use history, the mechanisms have been difficult to observe.

This paper investigates the influence of human land use on forest cover in private parcels in the Upper Midwest USA between 1970 and 1990. In particular, I examined forest-cover changes in relation to agricultural land use and dispersed rural land development. Although the spatial configuration (e.g., fragmentation) of forest is an outcome of the same processes described here, the paper examines only changes in the amount of forest. It is worth noting, however, that, to the degree that forest-cover patterns are driven by processes at the parcel scale, observed spatial patterns will likely reflect the imprint of land ownership patterns.

\section{Methods}

Forest-cover data for sample sites within the Upper Midwest were collected through satellite image classification and summarized over individual ownership parcels, acquired from archival maps. Amounts and changes in forest cover were analyzed in relation to land use, which was interpreted using parcel maps and aerial photo interpretation, and contextual information based on county socioeconomic profiles, which were summarized through a classification of county types. 


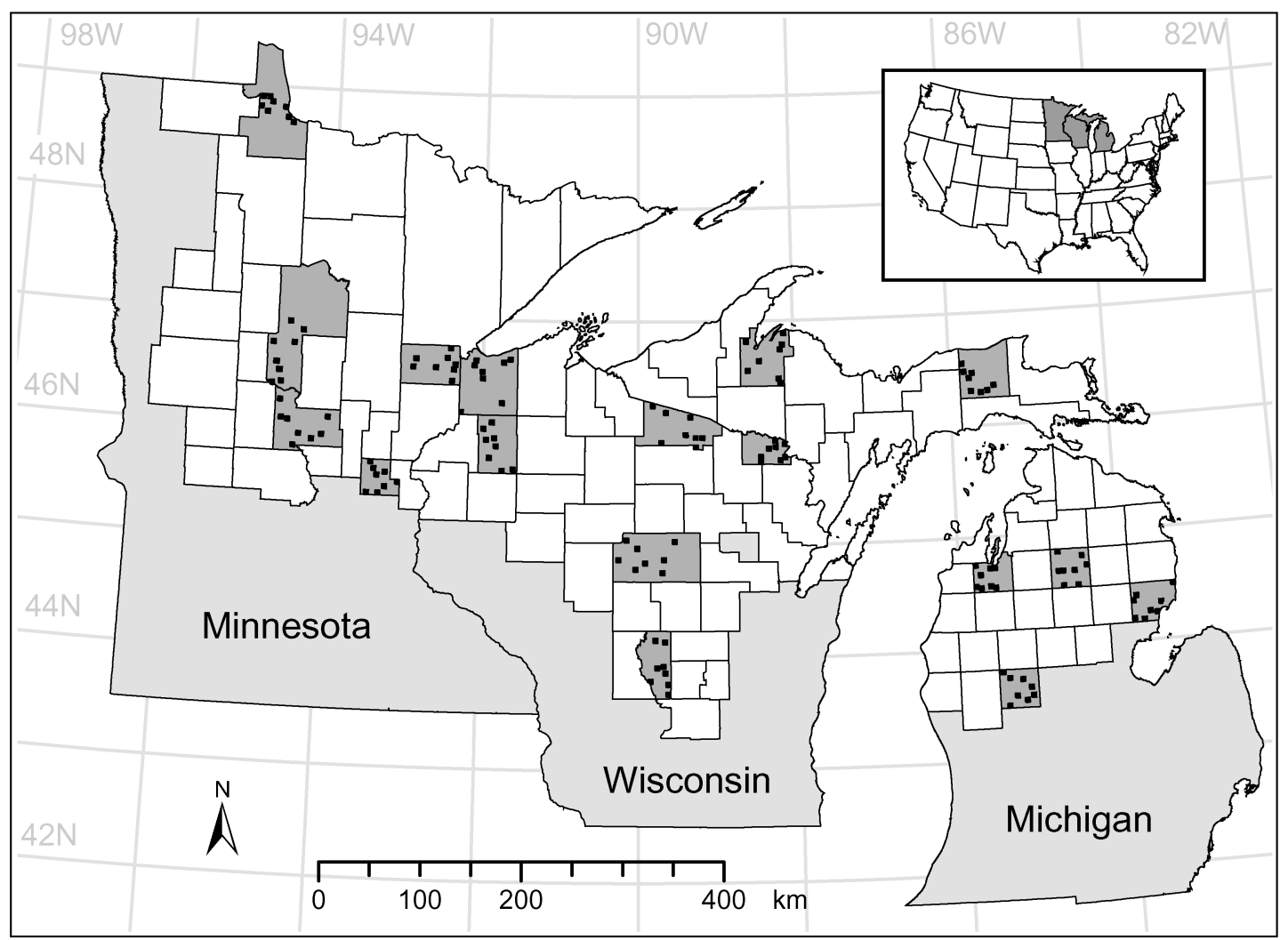

Figure 1. The study area with sample counties in darker gray and samples sites in black.

\section{Study area}

The study region, bounded by $43^{\circ} \mathrm{N}$ and $49^{\circ} \mathrm{N}$ latitude and $83^{\circ} \mathrm{W}$ and $96^{\circ} \mathrm{W}$ longitude, spans the northern forested regions of Michigan, Minnesota, and Wisconsin, USA (Figure 1). The study area was defined according to the ecoregions mapped by Omernik (1987) because they delineate relatively homogenous areas with respect to both natural variability and human land use. The selected ecoregions, labeled Northern Lakes and Forests, North Central Hardwood Forests, and Northern Minnesota Wetlands, contained 106 counties. The ecoregions in the study area are underlain by glaciated plains with sandy soils, interspersed with Precambrian mountains. Land cover is largely a combination of wetlands and forests. The region was nearly completely cleared for timber production or agriculture by 1920 (Williams 1989), but forest cover has increased steadily since. Recent forest inventories (Miles et al. 1995; Leatherberry and Spencer 1996; Schmidt 1997) reported that the area of forest land increased by between 0.25 and 0.5 million ha each in Michigan,
Minnesota, and Wisconsin over the 13-year period between the last two forest inventories. The primary forest was a mosaic of beech-maple, pine, and hemlock forests and the second-growth forest has been dominated by aspen.

The dominant land uses in the region are forest and pastureland. The forest products industry in the region has made use of the plentiful aspen forests for pulp and paper production. About one-third of the area in the region is under public ownership, but large areas of private corporate ownership also exist. Development for housing and recreation has become more extensive in recent decades, resulting in a fragmentation of the forest among many private landowners (Brown and Vasievich 1996; Drzyzga and Brown 2002).

Because of short growing seasons (fewer than 120 days throughout much of the region) and sandy or wet soils, the region is not generally productive in agriculture. Hay for livestock is common in many parts of the region and fruit grows in areas where the climate is modified by proximity to the Great Lakes. The amount of land area in crops throughout Michi- 
gan, Minnesota, and Wisconsin decreased by about 2.4 million ha between 1949 and 1992 (Waisanen and Bliss, 2002). Most of that decline occurred in the first half of the period, so the amount of decline was only 0.2 million ha between 1974 and 1992 .

Development has been driven to a large extent by recreational land uses (i.e., fishing, hunting, skiing, snow-mobiling, and boating), which have become increasingly important in recent years. Recreational land use activities tend to be regionalized; i.e., the character of activities and demographic mix of participants are variable among recreational destinations within the region (Hart 1984). Stynes (1997) estimated that, in 1990, tourism spending in the study area was about $\$ 4$ billion and, as a percentage of a county's total industrial output in 1990, ranged from less than 1 to about 41 percent. The largest share of tourism spending throughout the region was associated with seasonal home visits (about 42 percent of total tourism spending). The work of Stewart (1994) suggests that seasonal home development will result in increasing numbers of permanent residents. She surveyed seasonal homeowners and found that nearly half of them were over the age of 60 and that 40 percent listed "potential use as a retirement home" as a key reason for their decision to own a seasonal home. The conversion of seasonal homes to permanent residences probably will drive future demand for services and, therefore, development in the region.

\section{Sampling}

The region was sampled using an area-based sampling frame. Each sample conformed to a square block of nine survey sections (i.e., three by three), which were based on the public land survey system used in the United States after the mid-nineteenth century. Each survey section is $2.59 \mathrm{~km}^{2}$ (one square mile), so the sample sites averaged about 2500 ha (5760 acres) in size. The sampling scheme was hierarchically nested, such that I first selected 17 counties then, within each county, selected 8 sites.

In the first stage, the 17 counties (shown in Figure 1) were selected to characterize the regional scale variation in socioeconomic drivers. A total of 22 variables was collected or derived for all 106 counties from data reported in the US Census of Population and Housing from 1960, 1970, 1980, and 1990 (US Census Bureau). The variables selected were related to (a) characteristics and change in population and housing and (b) the relative importance of recreation versus other economic activities in the county. Selection of variables reflected a focus on the role of land use in driving land-cover change. The variables were analyzed through principal components analysis (PCA), to reduce statistical dimensionality, and cluster analysis (Ward's method) on the resulting components, to group the counties into types that exhibit similar patterns of socioeconomic characteristics and dynamics.

Four county types were identified as a result of the cluster analysis. The classification of counties into four types was evaluated by comparing the mean value of each variable among the four clusters using analysis of variance (ANOVA) (Table 1). County type labels were derived from an assessment of county type profiles based on the variable means listed in Table 1. High Growth Residential (HRES) counties were characterized by the largest population and housing totals and densities, highest growth in numbers of people throughout the period, highest percentage of urban population, and the smallest proportion of seasonal homes and tourism. High Growth Recreational (HREC) counties were those with the greatest percentage of seasonal homes and tourism, the smallest populations with the least percent urban, the greatest growth in percentage terms throughout the period, and the newest housing stock. Low Growth (LG) counties were characterized by the lowest rates of population and housing growth in real and percentage terms, the oldest housing stock, generally low population and housing densities, and a relatively small seasonal home and tourism sector. Medium Growth (MG) counties had the lowest population densities and smallest number of homes, with growth rates and levels of recreational activity that were intermediate among the county types.

I used the county classification as the primary stratification within which the counties were selected. Sample counties were selected manually from those in each category to (a) achieve a relatively even spatial distribution across the three states, (b) over sample rapidly growing counties to improve inferential power in these counties, and (c) focus on counties for which archival data were available. Of the 9 HRES counties in the region, 3 were selected: Grand Traverse, MI, Marathon, WI, and Isanti, MN. Of the 24 HREC counties, 5 were selected: Crawford, MI, Iosco, MI, Adams, WI, Vilas, WI, Cass, MN. Of the 39 MG counties, 4 were selected: Mecosta, MI, Florence, WI, Washburn, WI, and Lake of the Woods, MN. Of the 36 LG counties, 5 were selected: Baraga, 
Table 1. The mean values of census variables in each of the four county types (abbreviations are defined in the text). All variables listed have significantly different mean values $(\mathrm{p}(\mathrm{F})<0.05)$ and the variables are listed in order of decreasing F-value.

\begin{tabular}{|c|c|c|c|c|}
\hline \multirow[b]{2}{*}{ Variable } & \multicolumn{4}{|c|}{ County Types } \\
\hline & $\mathrm{LG}$ & MG & HREC & HRES \\
\hline$\%$ homes seasonal 1990 & 17.2 & 31.9 & 43.0 & 5.6 \\
\hline$\%$ homes built $<1960$ & 51.8 & 41.5 & 31.4 & 39.0 \\
\hline People per home 1980 & 2.2 & 1.7 & 1.4 & 2.7 \\
\hline$\%$ pop growth $70-80$ & 5.7 & 17.9 & 39.4 & 25.0 \\
\hline People per home 1990 & 2.0 & 1.6 & 1.4 & 2.5 \\
\hline Pop growth \# 70-80 & 1,445 & 3,268 & 3,973 & 9,849 \\
\hline$\%$ homes built $70 \mathrm{~s}$ & 22.2 & 27.1 & 31.3 & 27.3 \\
\hline Pop growth \# 60-70 & -370 & 517 & 2,079 & 7,261 \\
\hline$\%$ pop growth $80-90$ & -3.0 & 2.0 & 13.1 & 9.2 \\
\hline$\%$ change \# homes $70-80$ & 26.0 & 40.4 & 61.0 & 42.8 \\
\hline$\%$ pop growth $60-70$ & -1.6 & 2.5 & 24.5 & 19.2 \\
\hline People per sq mi 90 & 25.8 & 25.3 & 29.4 & 79.5 \\
\hline Change\% homes seasonal $80-90$ & 3.4 & 6.4 & 15.5 & 0.5 \\
\hline$\% 1990$ homes built in $80 \mathrm{~s}$ & 14.2 & 18.7 & 21.3 & 20.8 \\
\hline$\%$ pop urban 90 & 31.4 & 15.2 & 6.9 & 40.7 \\
\hline \# migrants $70-80$ & -8 & 2,288 & 3,241 & 4,136 \\
\hline \# seasonal homes 1990 & 2015 & 3937 & 5639 & 1465 \\
\hline$\% 1990$ homes built in $60 \mathrm{~s}$ & 11.8 & 12.7 & 16.1 & 12.8 \\
\hline$\%$ change \# homes $80-90$ & 7.3 & 12.3 & 14.7 & 16.9 \\
\hline Tourism as $\%$ of tot. ind. output & 3.6 & 9.8 & 14.5 & 1.9 \\
\hline Pop 1990 & 28,287 & 21,009 & 17,193 & 65,665 \\
\hline Pop growth \# 80-90 & -919 & 430 & 1786 & 4204 \\
\hline Median age 90 & 35.6 & 36.4 & 37.0 & 31.2 \\
\hline$\%<$ poverty 89 & 14.4 & 15.2 & 17.8 & 10.0 \\
\hline Change\% urban $80-90$ & -3.0 & 0.1 & 1.4 & 2.4 \\
\hline Rural\% pop growth $80-90$ & 3.0 & 21.3 & 11.6 & 4.4 \\
\hline \# homes 90 & 13,597 & 12,819 & 13,032 & 25,809 \\
\hline
\end{tabular}

MI, Luce, MI, Douglas, WI, Carlton, MN, and Morrison, $\mathrm{MN}$.

In the second stage, 8 sample sites were identified within each county. To focus the analysis on private lands, all sites were selected in areas that had no more than about 10 percent public ownership. To allow further exploration of the influence of finer scale locational factors on land-use and forest-cover change (results not reported here), counties were stratified into zones based on proximity to large lakes ( $>4$ ha), public lands, urbanized areas, and major roads. Proximity was defined using GIS buffers with widths of $3 \mathrm{~km}, 5 \mathrm{~km}, 8 \mathrm{~km}$, and $8 \mathrm{~km}$, respectively. Where possible, one sample each was taken at sites that were proximate (1) to all of these features, (2) to none of these features, and (3-6) to each one of these features but not any others (for a total of 6 samples). The remaining samples were selected for sites that exhibited some combination of proximity to two or three of these features. Because our ability to select sites that fell in each proximity zone was affected by the area in each zone in the county and because these zones were not strongly related to land-use and - cover change, little or no bias can be expected in this analysis as a result of the stratification.

\section{Land-use data}

The land ownership parcels were digitized from published plat books (Rockford Map Publishers 19651992). Within each sample site, land use was interpreted for all digitized parcels, collected within one or two years of 1970, 1980, and 1990 (Brown et al. 2000b). The land-use interpretation was carried out through on-screen labeling of parcel polygons that were visually displayed over aerial photographs. The air photos were collected at approximately the same time as the parcels. Technicians were trained to identify each of 27 different land-use types on the basis of (1) the patterns in the image, (2) the size of the parcel, and (3) ancillary information, like the name of the owner of the parcel or other map clues. Parcels 
were labeled with a primary, and if present, a secondary land-use type and the percentage of the parcel in each type was estimated.

Once all parcel polygons had been labeled for each date, a quality control process was initiated to evaluate the consistency of labels among interpreters and fix obvious errors. Possible errors were flagged by overlaying the parcel maps from all three dates and identifying four types of potential problems: (1) landuse changes that were unlikely (e.g., from dense development to agriculture); (2) change polygons that were assigned three different land-use types at the three different periods; (3) change polygons that "oscillated", i.e., they were assigned one label in the first and third period, but a second label in the second period; and (4) polygons that did not have a label for one of the periods. These flagged polygons were highlighted on screen with a view of the photos and polygons from each of the three dates. Technicians then changed labels that appeared to be wrong or incomplete given the information about all three dates.

In order to simplify the presentation of a very detailed data set, the contents of the data were summarized by primary land-use type only. Further the 27 land-use categories were combined into five major categories that were labeled as high density residential (HDRES), low density residential (LDRES), other developed (DEV), agriculture (AG), and natural (NAT). The HDRES category was defined as parcels with $>2.5$ residences per ha (about 1 per acre). LDRES parcels were smaller than 4 ha (10 acres) but had housing densities $<2.5$ per ha. The DEV landuse category included retail, industrial, infrastructure, transportation, cemeteries, and developed site-based recreation (including golf courses, campgrounds, marinas, and ski areas). The NAT land-use category refers to parcels that were not primarily used for residential or agricultural purposes. This includes parcels that had a house on them but were larger than 4 ha and were dominated by more natural land covers (e.g., forests and/or wetlands). Similarly, AG parcels were larger than 4 ha and could include a residence as long as the land in the parcel was predominantly used for agriculture.

\section{Forest-cover data}

Forest cover was mapped independently of land use for $60 \mathrm{~m}$ by $60 \mathrm{~m}$ pixels using an unsupervised classification of Landsat Multispectral Scanner (MSS) satellite image data. Land cover was mapped by clas- sifying 20 scenes from the North American Landscape Characterization (NALC) data set (Lunetta et al. 1998) to one of four classes: forest, nonforest, water, and other. Forest was defined as areas with $40 \%$ or more tree cover. The NALC data set consisted of images from the early-mid 1970s (1972-1975), midlate 1980s (1985-1987), and early 1990s (1990-1992) that had been georeferenced with an error of less than one pixel and, for the 1970s images, mosaiced to cover approximately the same scene footprints. Image processing steps are described in detail by Brown et al. (2000a), and included: manual identification and removal of clouds and cloud shadows (i.e., the "other" category); correction of radiometric values affected by haze, unsupervised classification of up to 50 spectral clusters, and labeling of clusters to one of the four land cover types. The unsupervised image classification was supported by the aerial photos covering each of the sample study sites. The northern half of each photo mosaic for each site was used as an aid in labeling spectral clusters to one of the five landcover classes. Fifty sample points were randomly selected within the southern half of each site, and labeled to land cover for use in accuracy assessment. Classification accuracies ranged from 66.7 to 94.5 percent, with the lowest accuracies observed at the earlier dates.

I compared forest-cover estimates from remote sensing with amounts of forestland estimated in the Forest Inventories and Analysis (FIA) data set from the USDA Forest Service (Jakes 1980; Raile and Smith 1983; Raile 1983; Miles et al. 1995; Leatherberry and Spencer 1996; Schmidt 1997). The proportion values were averaged by county type, a process that, in the case of both data sources, combines data collected across a range of dates within the 1970s, 1980s and 1990s. This fact, and important definitional differences between the data sets $^{1}$, makes strict numerical comparisons difficult. However, general trends are mostly consistent across the data sets.

\footnotetext{
${ }^{1}$ The definition of forest land used in the inventories was "Land at least 16.7 percent stocked by forest trees..., or formerly having had such tree cover, and not currently developed for nonforest use. The minimum area for classification of forest land is 1 acre, (though) roadside, streamside, and shelterbelt strips (that) have a crown width of at least 120 feet ... qualify as forest land." (Leatherberry and Spencer, 1996, p. 21).
} 
Analysis

Aggregate amounts of forest cover and land use were summarized by county type, then the changing proportions of forest cover on parcels were summarized by county type and land-use type. The forest-cover changes were compared with forestland estimates from the FIA dataset. To understand the drivers of the observed changes in land use, these dynamics were compared to other trends occurring in the region. First, parcels were identified that had experienced increases in their level of development. These included parcels where (a) the primary land use became a developed category from an undeveloped category or, (b) the primary land use was not developed, but the secondary land use changed to developed from undeveloped. The percent of land area in which the level of development increased was calculated for each time period, i.e., between the 1970s and 1980s and between the 1980s and 1990s, and compared with the rate of increase in the number of housing units reported by the US Census for the decades of the 1970s and the 1980s. Next, the percentage changes in agricultural land area were compared with changes in economic returns from agricultural investments ${ }^{2}$, calculated by the Agricultural Research Service.

By summarizing forest-cover amounts for parcels with different land-use types and in county types at each time period, I examined how forest-cover distribution was affected by land use and by the countyscale demographic and economic setting. Parcels were overlaid on the forest-cover maps and forest percentages were summarized by land-use type and county type. To deal with positional uncertainty in the overlaid parcels and images, a 5 by 5 filter was used to compute the probability that each cell was in forest, based on the proportion of cells in the filter window that were classified as forest. This probability value was averaged across all cells in a parcel to compute the percent forest cover in each parcel.

Next, the percentage of land area in forest in each land-use and county-type combination was calculated. The 95 percent confidence intervals are reported using the basic formulation of standard error for proportions:

\footnotetext{
${ }^{2}$ Calculation of returns is based on gross income versus costs, including risk, of crop production. Costs excluded marketing and storage costs. Income excludes loan deficiency payments which can be substantial for commodities when crop prices are low.
}

$$
1.96 \cdot \sqrt{\frac{p(1-\mathrm{p})}{n}}
$$

where $p$ is the percent forested and $n$ is the number of parcels in each land-use and county type combination. The value of $n$ was capped at 272 , i.e., two times the number of sample sites, in an attempt to avoid overestimation of the sample size. This reduced slightly the risk of violating the assumption of independence in parcel observations. Because of the large number of comparisons possible between county and land-use type combinations, I report only the confidence intervals for each number. Any two numbers in Table 4 can be considered significantly different ( $p>95 \%)$ if their difference is greater than the sum of their confidence intervals. Though care must be taken before drawing definitive conclusions about the differences when making a large number of comparisons, the magnitude of the differences, relative to confidence intervals, is instructive.

\section{Results}

\section{Changes in forest cover}

The first obvious trend in forest-cover patterns is the consistent difference between the HRES counties versus all other county types (Table 2). HRES is the smallest group of counties in the sample $(n=3)$ and averaged much higher population densities with economies that were much less reliant on tourism and seasonal homes than the other three county types (see Table 1). The only sample counties classified as "metropolitan" by the U.S. Office of Management and Budget were included in this group. Isanti County in Minnesota is part of the Twin Cities metropolitan area and Marathon County in Wisconsin part of the Wausau-Stevens Point metropolitan area. Perhaps more importantly, HRES counties had much more cropland per unit area than the other county types - 33 percent on average versus 7 to 11 percent according to the 1987 Census of Agriculture (USDA, 1987).

The second trend is a generally increasing amount of forest cover over time in all county types. The increases were not monotonic, but were most consistent across the data sources in the HRES and HREC counties between the 1980s and 1990s. The observed increases in forest cover were consistently higher in the satellite based data than in the forest inventory. In 
Table 2. Comparison of county-wide percent forest cover estimates for the 17 sample counties in each county type. FIA refers to the USDA Forest Service inventory data

\begin{tabular}{|c|c|c|c|c|c|}
\hline \multirow[b]{2}{*}{$\begin{array}{l}\text { County } \\
\text { Type }\end{array}$} & \multicolumn{2}{|l|}{ FIA } & \multicolumn{3}{|c|}{ This study } \\
\hline & $1980 \mathrm{~s}$ & $1990 \mathrm{~s}$ & $1970 \mathrm{~s}$ & $1980 \mathrm{~s}$ & $1990 \mathrm{~s}$ \\
\hline LG & 66.3 & 65.8 & 69.3 & 68.7 & 71.1 \\
\hline MG & 64.9 & 64.5 & 55.3 & 70.0 & 72.1 \\
\hline HREC & 69.3 & 71.8 & 68.7 & 65.8 & 71.6 \\
\hline HRES & 36.2 & 38.6 & 35.5 & 38.0 & 51.5 \\
\hline
\end{tabular}

fact, though the forest inventory showed slight declines for the medium and low growth counties between the 1980s and 1990s, the satellite-based data recorded slight increases.

\section{Changes in land use}

The first apparent land-use trend was an increase in developed land area. The greatest increases were in the low density residential land-use category in MG, HREC, and HRES counties, which increased three- to five-fold over the 20 year period (Table 3). Along with this increase in area came a similar increase in numbers of parcels in developed land uses, reflecting the fragmentation of ownership reported previously
(Brown and Vasievich 1996). Second, percentage of land in agriculture declined in all county types between the 1980s and 1990s, but held steady in the MG and HREC counties when observed over the entire period (1970s to 1990s). The number of agricultural parcels increased in those counties, but declined in the LG and HRES counties. Finally, the land in natural uses increased over the study period in the LG and HRES counties, but decreased in the MG and HREC counties. This change mirrors the relative changes in agricultural land area by county type, suggesting an interaction between the land in agricultural and natural uses.

The rate of increase in numbers of housing units was highest in the 1970 s, as was the rate of increase in the amount of area in parcels that were increasing their levels of development were highest in the 1970s, especially in parcels that fell in the HREC counties (Figure 2). The rate of increase in the numbers of housing units fell substantially in the 1980 s, reflecting the nationwide decline in the rate of growth in rural areas (Johnson and Beale 1998). Nonetheless, 5 to 8 percent of the area of sites in the high growth counties experienced increasing levels of development in the 1980s.

In general terms, the earlier period represented by the land-use data corresponded to a period of net positive returns from agricultural investment (Figure

Table 3. Land-use proportions in sample sites by county type. The number in parentheses indicates the number of individual plat-map polygons of each type.

\begin{tabular}{|c|c|c|c|c|c|}
\hline & \multicolumn{5}{|l|}{ County Types } \\
\hline & LG & MG & HREC & HRES & All \\
\hline Land Use & $1970 \mathrm{~s}$ & & & & \\
\hline HDRES & $0.1(5)$ & $1.1(8)$ & $0.3(18)$ & 0.8 (19) & 0.6 \\
\hline LDRES & $1.3(98)$ & $1.2(118)$ & $1.6(150)$ & $0.9(110)$ & 1.3 \\
\hline DEV & $1.1(24)$ & $0.8(24)$ & $5.0(39)$ & $3.2(52)$ & 2.4 \\
\hline $\mathrm{AG}$ & $38.0(628)$ & $42.3(893)$ & $33.4(539)$ & $68.1(1041)$ & 44.0 \\
\hline \multirow[t]{2}{*}{ NAT } & $59.5(961)$ & $54.7(1546)$ & $59.7(1752)$ & $26.9(636)$ & 51.7 \\
\hline & $1980 \mathrm{~s}$ & & & & \\
\hline HDRES & $0.1(4)$ & $1.2(16)$ & $1.0(58)$ & $0.8(44)$ & 0.8 \\
\hline LDRES & $1.8(194)$ & $2.5(285)$ & $5.1(681)$ & $2.5(296)$ & 3.1 \\
\hline DEV & $1.1(30)$ & $1.1(45)$ & $4.4(74)$ & $3.5(73)$ & 2.5 \\
\hline $\mathrm{AG}$ & $34.4(672)$ & $45.2(1072)$ & $35.2(758)$ & $63.6(1057)$ & 43.1 \\
\hline \multirow[t]{2}{*}{ NAT } & $62.6(1173)$ & $50.0(1616)$ & $54.3(2006)$ & $29.6(815)$ & 50.4 \\
\hline & $1990 \mathrm{~s}$ & & & & \\
\hline HDRES & $0.8(13)$ & $0.9(25)$ & $1.1(50)$ & $0.9(40)$ & 0.9 \\
\hline LDRES & $1.8(288)$ & $3.5(441)$ & $6.9(883)$ & $4.4(526)$ & 4.3 \\
\hline DEV & $1.0(34)$ & $1.9(66)$ & $6.2(91)$ & $3.6(96)$ & 3.3 \\
\hline $\mathrm{AG}$ & $30.6(605)$ & $42.4(1063)$ & $32.1(663)$ & $57.0(910)$ & 39.3 \\
\hline NAT & $65.8(1343)$ & $51.3(1810)$ & $53.8(2337)$ & 34.1 (1076) & 52.2 \\
\hline
\end{tabular}


Table 4. Percent forest cover on parcels by county type and land-use type, with 95 percent confidence intervals.

\begin{tabular}{llllll}
\hline & County Types & & & & \\
Land Use & LG & MG & HREC & HRES & All \\
HDRES & $1970 \mathrm{~s}$ & & & & \\
LDRES & $25.1 \pm 38.0$ & $21.8 \pm 30.6$ & $57.5 \pm 22.8$ & $17.9 \pm 18.2$ & $26.0 \pm 12.2$ \\
DEV & $33.3 \pm 9.9$ & $40.2 \pm 9.8$ & $45.6 \pm 8.1$ & $20.2 \pm 8.1$ & $37.4 \pm 5.8$ \\
AG & $26.6 \pm 18.1$ & $45.8 \pm 25.2$ & $33.1 \pm 15.0$ & $24.1 \pm 12.2$ & $31.4 \pm 7.7$ \\
NAT & $35.1 \pm 5.7$ & $38.3 \pm 5.8$ & $34.8 \pm 5.7$ & $22.7 \pm 5.0$ & $32.2 \pm 5.6$ \\
All & $82.4 \pm 4.5$ & $69.8 \pm 5.5$ & $64.7 \pm 5.7$ & $58.0 \pm 5.9$ & $70.4 \pm 5.4$ \\
& $63.1 \pm 5.7$ & $55.4 \pm 5.9$ & $52.8 \pm 5.9$ & $32.2 \pm 5.6$ & \\
HDRES & & & & & \\
LDRES & $1980 \mathrm{~s}$ & & & & \\
DEV & $5.0 \pm 21.4$ & $26.5 \pm 23.1$ & $37.4 \pm 12.5$ & $17.6 \pm 12.8$ & $27.8 \pm 8.0$ \\
AG & $21.1 \pm 7.2$ & $51.9 \pm 6.4$ & $55.2 \pm 5.9$ & $23.6 \pm 5.1$ & $48.0 \pm 5.9$ \\
NAT & $23.4 \pm 16.9$ & $41.5 \pm 17.6$ & $35.0 \pm 11.0$ & $23.5 \pm 10.6$ & $31.7 \pm 6.1$ \\
All & $81.5 \pm 5.4$ & $38.4 \pm 5.8$ & $32.2 \pm 5.6$ & $21.0 \pm 4.8$ & $30.4 \pm 5.5$ \\
& $61.8 \pm 5.8$ & $76.6 \pm 5.0$ & $68.9 \pm 5.5$ & $59.2 \pm 5.8$ & $73.6 \pm 5.2$ \\
HDRES & $57.7 \pm 5.9$ & $53.5 \pm 5.9$ & $32.5 \pm 5.6$ & \\
LDRES & $1990 \mathrm{~s}$ & & & & \\
DEV & $43.9 \pm 27.0$ & $31.9 \pm 18.3$ & $49.4 \pm 13.9$ & $22.3 \pm 12.9$ & $38.7 \pm 8.4$ \\
AG & $41.7 \pm 5.9$ & $51.7 \pm 5.9$ & $62.1 \pm 5.8$ & $38.9 \pm 5.8$ & $53.2 \pm 5.9$ \\
NAT & $24.4 \pm 14.4$ & $43.2 \pm 12.0$ & $52.5 \pm 10.3$ & $31.0 \pm 9.2$ & $44.5 \pm 5.9$ \\
All & $37.3 \pm 5.7$ & $39.2 \pm 5.8$ & $39.6 \pm 5.8$ & $32.8 \pm 5.6$ & $37.3 \pm 5.7$ \\
\hline
\end{tabular}
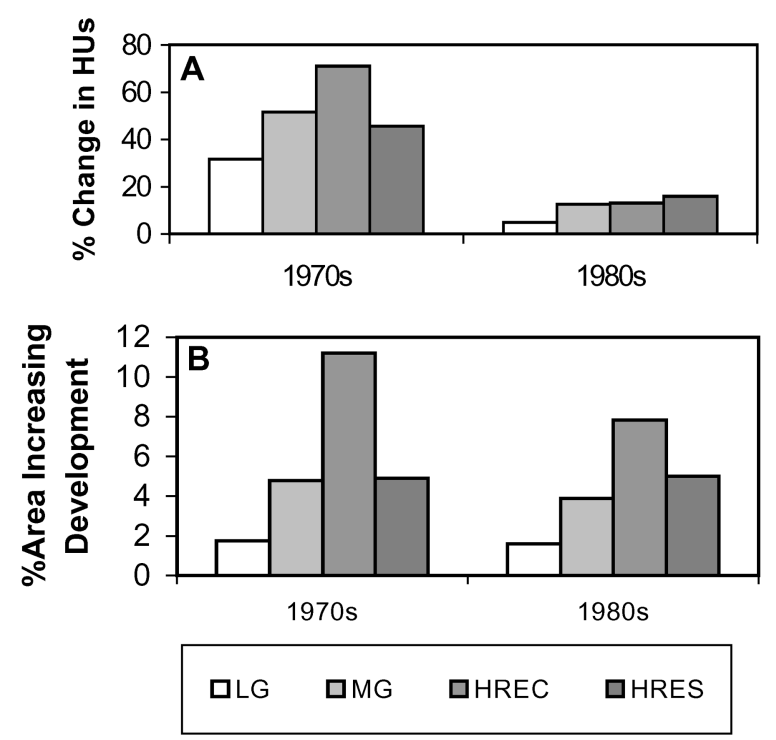

Figure 2. (A) Percentage rate of change in number of housing units and (B) percent of area increasing its level of development during the 1970 s and 1980 s.

3). At the same time, agricultural land area was increasing or relatively stable in the $\mathrm{LG}, \mathrm{MG}$, and HRES counties. Significant declines were seen in the most agriculturally developed of the counties (i.e., the
HRES counties). These declines were consistent with the longer term trends of agricultural abandonment and tended to occur on the sites that had less productive soils, no matter what type of county they were in (Brown et al. 2000a). When net returns to agricultural investments were negative beginning in the early 1980 s, i.e., farmers in the region began losing money on average, the effect on agricultural land use is quite apparent, with significant declines in agricultural land area in all county types.

\section{Forest-cover proportions by land-use and county type}

The first general observation of the data on percentage forest-cover by parcel is that natural land uses had the highest percentage of forest cover overall (70 $75 \%$ throughout the period). Agricultural lands had the lowest forest-cover percentage in the 1990s $(37.3 \%)$, but parcels in high density residential and other developed uses had lower forest-cover percentages than agriculture in the earlier periods. With only one exception (on agricultural lands between the 1970s and 1980s), forest-cover percentage increased on all land-use types over time. The largest increase, relative to confidence intervals, was that measured for 

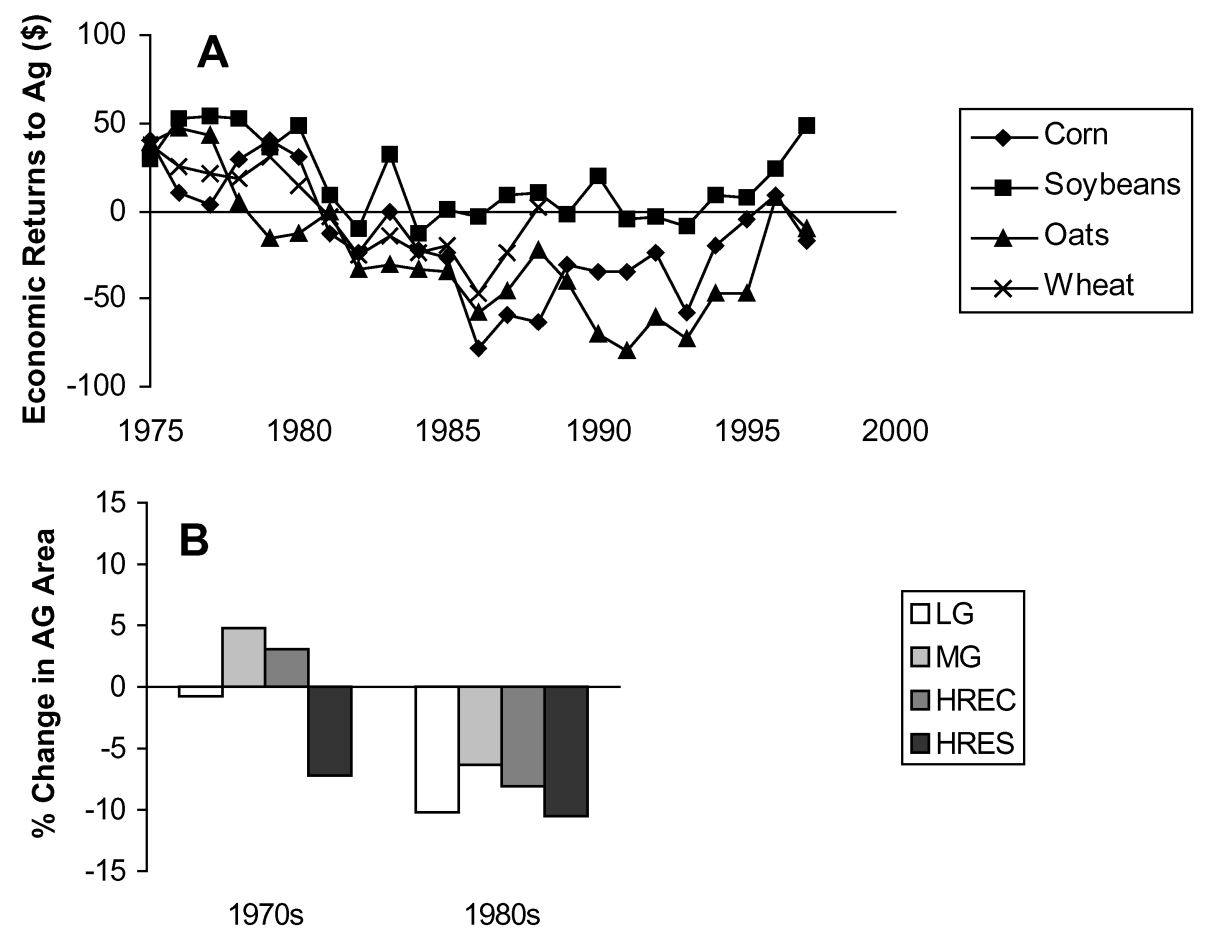

Figure 3. (A) Average returns to investments in crop production in \$ per planted acre and (B) percentage rate of change in the proportion of land used for agriculture.

low density residential land-uses between the 1970 s $(37.4 \%)$ and 1990 s $(53.2 \%)$.

Among county types, across all land-use types, LG counties had the most forest cover and HRES counties the least. This is largely a product of both differences in the amount of natural land use (Table 3) and the amount of forest cover on those natural lands (Table 4). LG counties had the second highest percentage of natural land use $(59.5 \%)$ and by far the highest percentage of that land that was forest covered $(82.4 \%)$. By contrast, HRES counties had the lowest percent of natural land uses $(26.9 \%)$ and the lowest percent of natural land use in forest cover (58.0\%). Lands in MG and HREC counties were forest covered at similar, moderate rates throughout the period of this study. Though the forest cover increased in all county types over time, none of the increases was high given the calculated confidence intervals.

Forest-cover percentages among county types and land-use types reveals several important differences (Table 4). First, there were big differences between the percentage of forest cover on low density residential parcels in the HREC (more) versus HRES (less) counties at all three dates. Second, compared to all other county types, agricultural lands tended to be much less forested, on average, in HRES counties. This suggests that much more of the agricultural land in these counties was used for crop versus pasture compared to the other county types. Third, low density residential parcels had much more forest cover than did agricultural parcels in the MG and HREC counties in the 1980s and 1990s.

Over time, there was a consistent trend of increasing forest cover on low density residential parcels across county types. The largest changes in forest cover over time were on the low density residential parcels in the HRES and HREC counties.

\section{Discussion and conclusions}

The results presented here illustrate how historical and contemporary human use of landscapes combine to shape the landscape dynamics that can be observed by satellite and forest inventories. Though forest cover increased across the landscape, in all county types and in all land-use types, there were notable differences in the rates of change. Though we can conclude that the general trend of increasing forest- 
cover was consistent based on data derived from satellite and from ground-based forest inventories (Table 1), it is difficult to obtain precise explanations for the differences between the numbers, given the differences in (a) definitions of forest, (b) dates of measurement, and (c) spatial sampling schemes.

Forest-cover dynamics on private lands in the Upper Midwest during the latter decades of the twentieth century were affected by a history of forest clearing, agricultural production on cleared lands, a contemporary decline in the agricultural economy, and increasing use of land for recreational and seasonal residential purposes. Although each of these processes was affected by the biotic and abiotic elements of landscape ecosystems to some degree, for example through impacts of soil quality and climate on agricultural productivity, they are also affected by socioeconomic processes that are exogenous to the region, for example changes in the prices of agricultural commodities. The importance of land use as a factor driving landscape change, and the sensitivity of land-use change to independent socioeconomic factors, reinforce the importance in landscape ecology theory and models of an integrated view of landscapes that includes biotic, abiotic, and anthropogenic patterns and processes.

By sampling and analyzing forest-cover change hierarchically, this study investigated how forest cover dynamics are influenced by both a parcel's land use and its regional setting. Land use described at the parcel level interacted with socioeconomic activity over larger areas, i.e., summarized at the county level because of available data, to provide a multi-level description of the impacts of land use on the forested landscape. The importance of land-use influences at multiple scales reinforces the importance of investigating landscape processes at multiple scales.

Natural lands, including those where forestry was being practiced, were most common in Low Growth (LG) counties and had the greatest percentage of forest cover. LG counties were the most remote and most likely to still have had significant extractive economies, especially in the forest industry. Perhaps counter-intuitively, the most rapid increases in forest cover were observed in the counties that experienced the highest rates of population growth - i.e., HREC and HRES counties. The absolute amount of forest cover was very different between the HREC and HRES counties; i.e., the HREC counties had much more. This difference might be explained by either differences in the kind of development that was oc- curring or the differences in the land-use histories of these county types. Both explanations are likely correct, as the HREC counties tended to experience substantially more second home development than the HRES counties and there was much more initial land in agriculture in the HRES counties. The population density in these HRES counties might be attributable to more productive agricultural land, which explains lower levels of land in forest. These findings highlight the risks involved in simplistic views of anthropogenic influences on landscapes; i.e., given the diversity of land-use histories and types of development, information about population growth at a coarse grain is insufficient to draw conclusions about likely landscape changes.

In the high growth counties (i.e., HRES and HREC), increases in forest cover were most rapid on low density residential parcels. There are two possible explanations for the increase in the percent forest cover on these low density residential lands. A first is that these lands, when taken out of agricultural or natural resource production activities, were left to regrow to forest, which has important amenity values for recreational land users that were maintained when the lands were developed. A second explanation is that, because many of these lands were developed for recreational activities and seasonal homes, the development may have occurred preferentially on already forested lands, thereby increasing the percent forested across all lands in this use. Again, the real explanation is likely a combination of these two. This discussion points to the importance of interaction between human activity and landscape structure in landscape evolution. An integrated view of landscapes, i.e., one that includes both ecological and socioeconomic processes, needs to accommodate the interactions and feedbacks between landscape structure and human decision making.

The importance of forest cover on lands used for recreational development is apparent in the increasing difference in forest-cover percentages on low density residential versus agricultural lands in the MG and HREC counties. Because homes were more likely to be seasonal homes in these two county types, 32 and 43 percent on average respectively, than in the other types, the residential land parcels were more likely to be characterized by natural amenities, including forest cover. The data clearly indicate that increases in forest cover were not incompatible with the dispersed rural residential development that was occurring in the region. The effect of development on 
forest cover was clearly variable across the landscape. Development in areas associated primarily with recreational activities tended to have more forest, and more rapidly increasing forest cover. Though it may be inaccurate to draw a causal link, as many of the forests are growing back on a longer time scale because of agricultural abandonment, the significant increase in the percentage forested on low density residential lands in the MG and HREC counties highlights an increasing role of recreation, seasonal homes, and large lot development in the evolution of forest cover throughout the Upper Midwest. Because recreation-based development is driven by the access land provides to opportunities for fishing, hunting, boating, snow-mobiling, and skiing, among other activities, land-use models based on urban growth theory are likely quite inadequate to account for these development patterns (Shellito 2001). Further, the interactions between landscape structure, its effects on recreational development, and subsequent effects on landscape structure render static or linear models of landscape evolution inadequate.

The observed increases in forest cover have two significant potential implications: increased carbon sequestration and increased forest habitat for wildlife species. However, there are several reasons why these benefits might be short-lived or not as beneficial as they could be. First, because it is impossible for the forest-covered area to increase indefinitely, the area of forest must level off at some point. Though forest regrowth and development co-existed in the 1970s and 1980s in the Upper Midwest, there is no guarantee that forest regrowth can continue should development continue apace. Indeed, it seems likely that increasing amounts of dispersed development will hasten that levelling off. Forest area has already stopped increasing in New England (Foster 1995). Second, the functional differences between these forests and large tracts of undeveloped forest merit investigation. It is not likely that forests with houses interspersed in the understory and with intense human occupation have the same levels of productivity, and store carbon at the same rate, as forests growing in natural stands. There is evidence that human activity can reduce the suitability of an ecosystem for wildlife, even if the vegetation canopy is suitable and the activity is as benign as walking on a trail (Knight and Gutzwiller 1995). So, it is very unlikely that the forest cover on these rural residential lands serves the same wildlife habitat purpose as larger tracts of natural forest. Further work is needed on the quality of forest ecosystems that co-occur with dispersed development to better understand the carbon and wildlife implications of increased forest cover in human inhabited landscapes, as human habitation continues to spread across the rural landscape. Finally, the ownership of landscapes and forests has become increasingly fragmented during the period of this studyi.e., more and smaller parcels over the same area in the 1990s than in 1970s. In terms of forest management, these forests on large lot residential land parcels are effectively unavailable for forest clearing, thinning or other forest management practices. This likely has negative effects on the productivity of the forest and on availability of management options.

\section{Acknowledgments}

The author thanks Bryan Pijanowski and Mike Vasievich for their contributions to various aspects of the project and R. Boehm, E. Clark, S. Drzyzga, J-D. Duh, T. Jones, J. Krawczyk, S. Savage, B. Shellito, and A. Thomas for help in preparing the data. The work was supported by grant NAG5-6042 from the Land Cover and Land Use Change (LCLUC) Program of the National Aeronautics and Space Administration (NASA), with additional support from the North Central Research Station of the U.S. Forest Service.

\section{References}

Allen T.H.F. and Starr T.B. 1982. Hierarchy, Perspectives for Ecological Complexity. University of Chicago Press, Chicago, Illinois, USA.

Bailey R.G. 1996. Ecosystem Geography. Springer, New York, New York, USA.

Brown D.G., Duh J.D. and Drzyzga S. 2000a. Estimating error in an analysis of forest fragmentation change using North American Landscape Characterization (NALC) Data. Remote Sensing of Environment 71: 106-117.

Brown D.G., Pijanowski B.C., and Duh J.-D. 2000b. Modeling the Relationships between Land-Use and Land-Cover on Private Lands in the Upper Midwest, USA. Journal of Environmental Management 59: 247-263.

Brown D.G. and Vasievich J.M. 1996. A Study of Land Ownership Fragmentation in the Upper Midwest. Proceedings, GIS/LIS '96 Conference, Denver, Colorado, USA, p. 1199-1209.

Burgess R.L. and Sharpe D.M. (ed.), 1981. Forest Island Dynamics in Man-dominated Landscapes. Springer, New York, New York, USA. 
Caspersen J.P., Pacala S.W. Jenkins J.C., Hurtt G.C., Moorcroft P.R. and Birdsey R.A. 2000. Contributions of land-use history to carbon accumulation in U.S. Forests. Science, 290: 1148-1151.

Delcourt H.R. 1987. The impact of prehistoric agriculture and land occupation on natural vegetation. Trends in Ecology and Evolution 2: 39-44.

Drzyzga S.A. and Brown D.G. 2002. Spatial and temporal dynamics of ownership parcels and forest cover in three counties of Northern Lower Michigan USA, ca. 1970 to 1990. In: Walsh S.J. and Crews-Meyer K.A. (eds), Linking People, Place, and Policy: A GIScience Approach. Kluwer, Dordrecht, The Netherlands, pp. $155-185$.

Fan S., Gloor M., Mahlman J., Pacala S., Sarmiento J., Takahashi T. and Tans P. 1998. A large terrestrial carbon sink in North America implied by atmospheric and oceanic carbon dioxide data and models. Science 282: 442-446.

Foster D. R. 1992. Land-use history (1730-1990) and vegetation dynamics in central New England, USA. Journal of Ecology 80: 753-772.

Grübler A. 1994. Technology. In: Meyer W.B. and Turner B.L. (eds), Changes in Land Use and Land Cover: A Global Perspective. Cambridge University Press, New York, New York, USA, pp. 287-328.

Hart J.F. 1984. Resort areas in Wisconsin. Geographical Review 74: $192-217$.

Huston M. 1993. Biological diversity, soils, and economics. Science 262: 1676-1680.

Jakes P.J. 1980. Minnesota Forest Statistics, 1977. USDA Forest Service, North Central Forest Experiment Station, St Paul, Minnesota, USA.

Jenerette G.D. and Wu J. 2001. Analysis and simulation of landuse change in the Central Arizona-Phoenix Region, USA. Landscape Ecology 16(7): 611-626.

Johnson K.M. and Beale C.L. 1998. The rural rebound. Wilson Quarterly 12: 16-27.

Knight R.L. and Gutzwiller K.J. (eds), 1995. Wildlife and Recreationists. Island Press, Covelo, California, USA.

Lant C., Loftus T., Kraft S., Bennett D. 2001. Land-use dynamics in a southern Illinois (USA) watershed. Environmental Management 28(3): 325-340.

Leatherberry E.C. and Spencer J.S. 1996. Michigan Forest Statistics, 1993. Resource Bulletin NC-170. USDA Forest Service, North Central Forest Experiment Station, St Paul, Minnesota, USA.

Levin S.A. and Paine R.T. 1974. Disturbance, patch formation and community structure. Proceedings of the National Academy of Science 71: 2744-2747.

Lunetta R.S., Lyon J.G., Guindon B., and Elvidge C.D. 1998. North American Landscape Characterization dataset development and data fusion issues. Photogrammetric Engineering and Remote Sensing 64(8), 821-829.

Medley K.E., Okey B.W., Barrett G.W., Lucas M.F. and Renwick W.H. 1995. Landscape change with agricultural intensification in a rural watershed, Southwestern Ohio, USA. Landscape Ecology 10(3): 161-176.

Meyer W.B. 1995. Past and present land use and land cover in the USA. Consequences, Spring 1995: 25-33.

Miles P.D., Chen C.M. and Leatherberry E.C. 1995. Minnesota Forest Statistics, 1990, Revised. Resource Bulletin NC-158. USDA Forest Service, North Central Forest Experiment Station, St Paul, Minnesota, USA
Nagashima K., Sands R., Whyte A.G.D., Bilek E.M., Nakagoshi N. 2002. Regional landscape change as a consequence of plantation forestry expansion: an example in the Nelson region, New Zealand. Forest Ecology and Management 163 (1-3): 245-261.

Okubo A. 1975. Ecology and Diffusion. Tsukiji Shokan, Tokyo, Japan.

Omernik J.M. 1987. Ecoregions of the Conterminous United States (map supplement). Annals, Assoc. of American Geographers 77(1): 118-125.

Pastor J., Dewey R.J., Naiman P.F., McInnes P.F. and Cohen Y. 1998. Moose browsing and soil fertility in the boreal forests of Isle Royale National Park. Ecology 74: 467-480.

Pickett S.T.A. 1982. Population patterns through twenty years of old-field succession. Vegetatio 49: 45-59.

Raile G.K. 1983. Wisconsin Forest Statistics, 1983. Resource Bulletin NC-94. USDA Forest Service, North Central Forest Experiment Station, St Paul, Minnesota, USA.

Raile G.K. and Smith W.B. 1983. Michigan Forest Statistics, 1980. Resource Bulletin NC-67. USDA Forest Service, North Central Forest Experiment Station, St Paul, Minnesota, USA.

Rockford Map Publishers 1965-1992. Land Atlas and Plat Books. Rockford Map Publishers, Inc., Rockford, Illinois, USA.

Schmidt T. 1997. Wisconsin Forest Statistics, 1996. Resource Bulletin NC-183. USDA Forest Service, North Central Forest Experiment Station, St Paul, Minnesota, USA.

Shellito B.A. 2001. Spatial modeling of seasonal homes in the Upper Great Lakes States. Paper presented at the Southeastern Division of the Association of American Geographers 2001 meeting, Lexington, Kentucky, USA, November 17-20.

Stewart S.I., 1994. The Seasonal Home Location Decision Process: Toward a Dynamic Model. Ph.D. Dissertation. Department of Parks and Recreation, Michigan State University, East Lansing, Michigan, USA.

Stynes D.J. 1997. Recreation activity and tourism spending in the Lake States. In: Vasievich J.M. and Webster H.H. (eds), Lake States Regional Forest Resources Assessment: Technical Papers. General Technical Report NC-189, North Central Forest Experiment Station, St Paul, Minnesota, USA, pp. 139-164.

Swanson F.J., Kratz T.K., Caine N. and Woodmansee R.G. 1988. Landform effects on ecosystem patterns and processes. BioScience 38: 92-98.

Turner B. L., Skole D., Sanderson S., Fischer G., Fresco L. and Leemans R. 1995. Land-Use and Land-Cover Change Science/ Research Plan. Joint publication of the International GeosphereBiosphere Programme (Report No. 35) and the Human Dimensions of Global Environmental Change Programme (Report No. 7). Royal Swedish Academy of Sciences, Stockholm, Sweden.

U.S Census Bureau 1960-1990. US Census of Population. Government Printing Office, Washington, DC, USA

U.S. Department of Agriculture 1987. US Census of Agriculture. National Agriculture Statistical Service, Washington, DC, USA.

Waisanen P.J. and Bliss N.B. 2002. Changes in population and agricultural land in conterminous United States counties, 1790 to 1997. Global Biogeochemical Cycles, 16(4): 1137, doi: 2001 GB001843.

White P.S. and Pickett S.T.A. 1985. Natural disturbance and patch dynamics: an introduction. In: Pickett S.T.A. and White P.S. (eds), The Ecology of Natural Disturbance and Patch Dynamics, Academic Press, New York, New York, USA, pp. 3-13. 
Williams M. 1989. Americans and their Forests. Cambridge University Press, New York, New York, USA 